This item was submitted to Loughborough's Research Repository by the author.

Items in Figshare are protected by copyright, with all rights reserved, unless otherwise indicated.

\title{
A pint to remember: the pub as community militarism
}

\section{PLEASE CITE THE PUBLISHED VERSION}

https://doi.org/10.1080/23337486.2020.1750261

\section{PUBLISHER}

Taylor and Francis

\section{VERSION}

AM (Accepted Manuscript)

\section{PUBLISHER STATEMENT}

This is an Accepted Manuscript of an article published by Taylor \& Francis in Critical Military Studies on 14 Apr 2020, available online: https://doi.org/10.1080/23337486.2020.1750261

\section{LICENCE}

CC BY-NC-ND 4.0

\section{REPOSITORY RECORD}

Partis-Jennings, Hannah. 2020. "A Pint to Remember: The Pub as Community Militarism". Loughborough University. https://hdl.handle.net/2134/12129999.v1. 


\title{
A Pint to Remember: The Pub as Community Militarism
}

Hannah Partis-Jennings, Loughborough University

\begin{abstract}
This article focuses on The Don War Memorial Bar in Stockton-upon-Tees as a themed space. This space 'made' through embodied labour, martial images and objects and practices of care and compassion as well as of mourning forges an emotional community that signals specific political effects in times of austerity and in relation to potential immunity for atrocity crime in the context of British imperial war-making (specifically focusing on Northern Ireland). This article builds on diverse and multidisciplinary insights to explore the understudied space of the war-themed pub as a crucial site of everyday liberal militarism delineated by aesthetic and material modes of immersion, memorialisation and affective praxis. It makes a significant contribution to ongoing conversations about martial memory-curation and the significance of emotional nationalism crafted through banal sites of encounter and embodied performances. Moreover, it further highlights the importance of the pub, especially in the context of the UK, to 'everyday $I R^{\prime}$ and complex configurations of national atmospheres and geopolitical ritual.
\end{abstract}

Keywords: Pub, Memorial, Military, War, Community, Austerity, Images, Themed Space

\section{Introduction}

This article provides an analysis of unexplored spaces within critical military studies scholarship, namely war/military themed bars in general and one in particular. International Relations (IR) has only just begun to take interest in pubs as political spaces in which alcohol, in all its 'vibrant' materiality (Bennett 2010), is imbibed by particular bodies and spaces are rendered in powerfully political ways (Saunders and Crilley 2019; Saunders and Holland 2018) while conflict research is increasingly drawn to a focus on spatial praxis (cf. Kothari 2006). In the context of austerity politics in Brexit Britain, whereby 'public support for the reduction or withdrawal of welfare entitlements' is fostered 'through appeals to ... self-sufficiency' (MacLeavy 2011, 355 cited in Basham 2016b, 259), as well ideas of collectivity epitomised by Osborne's 'we're all in this together' (Closs Stephens 2016, 190 ) and Thatcher's 'care in the community' (BBC News 1999), pubs can have a particular role as 'community-fixers' (Hubbard 2019). Austerity in Britain shrinks the responsibilities of the state, and arguably relies for its ideational fodder on a powerful reification of the (violent) past, venerating the soldier/veteran as an abstract figure bound to the generation of national feeling in the face of often alienating neoliberal governance (see Andrews 2017). This gives spaces of informal war-theming a particular political value.

The Don War Memorial Bar in Stockton-upon-Tees (hereafter The Don), named 'Britain's best pub' by The Sun newspaper in May 2019 (Ridley 2019), is run by Julie Cooper, who is often at the centre of online publicity surrounding the establishment. Cooper is reported to have begun collecting and displaying photos and poppies in her pub seven years ago (Ridley 2019). She explained to a Daily Mail (Duel 2015) reporter that:

I just did a small war memorial at the bar, it was covered in poppies, and I put photos of Lee Rigby up because I feel very strongly about his story. . . Mums and dads then started sending photos of their sons and daughters - current and ex-servicemen - which I put up. . Parents 
asking me to put them up is a honour for us. They just want to see their photos on display somewhere else. Sometimes when I finish here I'm on my own, I finish up and look at them. They've all got the same look in their eyes - of pride [sic].

The owner's words demonstrate that this pub emerged as a war/military-themed memorial space via the story of Lee Rigby (which I refer to again below) and though modes of community curation, mourning, participation and emotionality (evidenced by the ideas of strong feelings, honour and pride that Cooper talks about here).

The geographical location of the bar is one notable in part for large-scale income disparity, and deprivation. As of 2018, Stockton-upon-Tees had the largest life expectancy gap (driven by income inequality) of any town in England (Bilton 2018). In 2017 The Guardian (Halliday 2017) highlighted that 'unemployment across the Tees Valley is double the national average at 3.9\%. The number of jobless youth is higher, at 5.2\%, compared with the national average of 2.3\%.' Additionally, Stockton and nearby Darlington are top regions for military recruitment (Dempsey 2019, 12-13).

The Don is notable for acting as a kind of living museum where families and friends of loved ones can send photographs of soldiers killed in war to be displayed. Other artefacts of war, such as a ration booklet, uniforms, a metal sign warning of mines, flags, grenades, medals, wooden crosses and memorial poppies (over 70,000 see TSB 2018) are on show throughout the pub and indeed cover and use up every available wall and ceiling space. In order to better understand The Don as a site of affective, everyday martial politics, I draw upon a multidisciplinary literature around themed and immersive spaces. Lukas (2007) writes about 'themed space' (relying on the 'use of an overarching theme' (2007: 1)) as immersive, performative, dependent on sets of symbols and co-ordinated 'myths'. As Lukas argues '[t]he principles of theming are simultaneously the products of nation and help to construct nation'. Themed spaces produce a mode of stimulation, that 'is always a political project' (Lukas, 2007: 8) where experiential sense-making is created (and curated) through thematic alignment. More significantly than many (perhaps any) other war/military-themed or war-linked bars in the UK, the identity of The Don, by virtue of its deep relationship to military memory, emotive curation and military communities, parallels that of a memorial or community museum and offers insight into the ways that sites of war-memorial are made and felt.

The contribution of this article is two-fold; firstly it examines the military-themed pub as an unexplored site within critical military studies (CMS) and IR, highlighting the usefulness of the idea of 'theming' and pubs as 'community-fixers' for understanding sites of martial atmosphere, emotional militarism and the hybrid space between state and everyday militarism (cf. Basham 2018, 34). This contributes directly to literature in CMS by exploring affective martial space in new ways. Secondly, contributing to literature on aesthetics, affect and immersive spatial praxis in IR, it posits the idea of 'elision' (the sliding together of different elements, obscuring aspects of the original) as a form of politics, whereby the notion of the veteran is felt intimately as a symbolic, emotive and aesthetic signifier. I suggest that this logic is visible as part of theming praxis in The Don, and that it maps onto wider discursive trends evident in interest group and elite political rhetoric centred around the 'Justice for Northern Ireland Veterans' campaign and related issues.

Before outlining my methodology and proceeding to the body of the article, I will briefly outline the background to 'Bloody Sunday' in Northern Ireland, and 'Soldier F'. The 'Troubles' in Northern Ireland (1969 - 1998) stemmed from historic colonial resettlement practices and the marginalisation and mistreatment of a large Catholic minority (favouring a Protestant, more privileged majority, mostly seen as loyal to the British State) (cf. Burke 2018; Kennedy-Pipe 1997). The British army initially arrived as a stabilization force, but soon ended up involved in a war with the Irish Republican 
Army (IRA), a violent anti-imperialist militia. This escalation of the conflict was linked in part to atrocities committed by military personnel (though there were many other factors as well). ${ }^{1}$ One of these atrocities was 'Bloody Sunday', which happened on Sunday 30 January 1972 when soldiers opened fire on peaceful civil rights protestors in Derry, killing thirteen (Kennedy-Pipe 1997, 60 -1). ${ }^{2}$ The killings had a momentous political and traumatic significance and symbolised to many a wider brutality against the Irish that had arguably characterised British colonial involvement with the island for hundreds of years (cf. Conway 2003). Today, historical prosecutions for crimes during the socalled 'Troubles' in Northern Ireland have been initiated by the Public Prosecution Service and have faced considerable backlash and controversy (see McGuinness 2019). 'Soldier F' is one of those facing prosecution, for his alleged participation in the crimes of Bloody Sunday (see Roberts 2019). While I cannot do justice to the complexities involved in these cases and their relationship to the 'Troubles' and the Good Friday Agreement within the scope of this piece, I do return to the case of Soldier $\mathrm{F}$ towards the end of this article, highlighting how theming practices and ideas of the veteran in The Don and more broadly, contribute to a particular politics.

\section{Approaching Themed Space}

In this paper I entangle multiple intersecting 'readings' in order to explore The Don as a themed space (see Tidy 2019). I 'read' the many images and posts available online via public forums such as Facebook, Twitter and the tourist review site Tripadvisor (2020) as well as 176 of my own photographs of the bar from two visits. I read these with attention to categories outlined by Lukas and Holtorf for recognising theming strategies, in particular 'semiosis' and the use of 'pastness'. Semiosis refers to how 'spaces rely of forms of semiotic admixtures in which disconnected or unrelated symbols, things and qualities are brought together in what appears to be a unified and meaningful whole' (Lukas 2016, 10). While 'pastness' is 'different from age and denotes the perceived quality that a given object is of the past' (Lukas 2016, 8). In doing this form of reading I pay attention to both Bleiker (2015) and Hutchison's (2016) insights that images are understood at least in part through emotions. I also engage modes of encounter used in CMS and feminist scholarship as well as literature within the aesthetic turn, including Shapiro's 'slow looking' (2008) (repeatedly returning to the same images), an attentiveness to material objects and their intended martial symbolism as well as militarised curation and the process of 'making' (drawing on Tidy 2019)(in this case) a space through embodied effort. A feminist methodological orientation in this article fuels an interest in 'everyday IR' (Åhäll 2019) embodied curation and the affective atmospheres generated by images, objects and theming praxis. Importantly, though I pay attention to specific images and items, I am also interested in understanding the thematic and affective dynamics elucidated by images read in multiples and categories (such as photographs of deceased soldiers). My visual analysis is explicitly a reading of intertextual material encountered publically (cf. Bleiker 2018).

I also 'read' my own experience of visiting The Don on two occasions eight months apart in 2019, for a few hours in total. This participation in the space of The Don draws on Åhäll's notion of 'affect as methodology' (Åhäll 2018) and notions of 'atmosphere' taken from critical geography (Closs Stephens 2016). While in The Don I had some informal conversations (and asked permission to take pictures) but these conversations are not included in this research as I wanted to focus on the public elements of The Don (physically and online). To do this I draw on my embodied experience of what might be called a 'tourist' performativity (Edensor 2001) (or, in theming terminology the 'guest role/drive' (Lukas 2016, 4))- entering an unfamiliar and unusual space as an outsider, trying to

\footnotetext{
${ }^{1}$ For a discussion of atrocity and the British Army in Northern Ireland see Burke 2018.

${ }^{2}$ The British Army contested this and claimed that soldiers were acting in self-defence (Kennedy-Pipe 1997, 601).
} 
engage with its atmosphere and theme and taking photographs of interesting elements. This reflexive approach offers access to how The Don functions as a themed space that is felt and encountered. Though of course, this 'tourism' happens within the parameters of my (femalegendered, white-raced, middle-classed and Irish) positionality as a researcher, it is important to note that my first visit aligns with a kind of methodological 'groundedness' (cf. Basham 2009, 730) as I was primarily just curious about the space and what it might feel like as well as what I would see. Similarly, by way of comparison, I visited (again spending an hour or two in each) other pubs/bars with a war-linked theme in some way, namely Cahoots Underground, The Brigadiers and The Nags Head, to gauge the similarities and differences between these and The Don as a backdrop to my analysis. This echoes the site-specific spacio-ethnographic readings of pub politics evident in other scholarship (Hubbard 2019; Saunders and Crilley 2019) and factors in elements of geographic particularism, notably that these other pubs are in London as opposed to Stockton-upon-Tees and thus subject to fundamentally different regional and commercial significance/meaning and ideas of 'community'.

Additionally, I conduct a discourse analytical reading (open to sensations, emotions, affects and atmospheres) of fifteen publicly available online media articles and two short films about The Don, one made by the BBC, and another by a bank, Permanent TSB. The BBC Radio Tees (2016) film is just under two minutes long and focuses on solely on owner Julie Cooper with a lot of close up footage of items in the pub $^{3}$ while the TSB (2018) one is nine minutes long and includes more extensive footage of the bar and interviews with Copper and with multiple veterans who frequent the pub. ${ }^{4}$ Each of the videos is a hybrid between a kind of 'local interest' exploration, a promotional exercise for this site, and a reiteration of certain spaces as 'community-fixers' within the wider context of social fragmentation and austerity in contemporary Britain (Hubbard 2019). Finally, I critically read the website and social media profile of the Justice for Northern Ireland campaign, and political statements relevant to the prosecution of British veterans for alleged historical crimes while serving in Northern Ireland, namely the killing of unarmed civilians.

\section{Reading 'The Don'}

Is this a pub or a museum? It doesn't matter, make a visit and enjoy the experience.

\section{- Extract from Tripadvisor Review of The Don}

The Don is a space of war memorialisation marked both by war ephemera and war dead, which though in keeping with a much larger (understudied) tradition of war-themed bars in the UK ${ }^{5}$, is marked out by its immersive scale, emotionality and the deep and intimate sense of community that it evokes. Memorialising war plays a key role in the construction of social orders, it can legitimise the state and sanction its violence and can help to forge 'communities of feeling' (Berezin 2002, 44 cited in Basham, 2016: 885) in which the 'grievability' (Butler 2010) of certain lives is politically constituted while the lives of others are rendered forgettable or are erased from view (Welland 2017). Memorialisation processes are partially about marking the dead, primarily dead soldiers, those sacrificed on behalf of the state and wider political community (Danilova 2015; Sylvester 2019) and in The Don these dead soldiers are hugely in evidence, signalled by images of those soldiers taken when they were alive that are stuck up all around the walls as well as wooden crosses with names and images of dead soldiers attached to them, and (more indirectly) hundreds of thousands of small

\footnotetext{
${ }^{3}$ This video has 41,500 views

${ }^{4}$ This video has 5,200 views.

${ }^{5}$ With thanks to a reviewer for clarifying this point.
} 
memorial poppies, the symbol of both British war dead, and support for the British military (Basham 2016a). Civilians are visible, such as brides getting married to soldiers or victims of war (including some pictured in Nazi camps) but the primary visual focus of the space, thematically read, is predominately, though certainly not exclusively, white, male, uniformed soldiers, some of whom are specifically signalled as deceased by text accompanying their image. A text box might be added to the image to indicate rank, name, age and cause of death for instance and sometimes the images are part of posters designed to incorporate multiple images and the text might read like an initial notification of death starting - 'with deep sadness I have to inform you of the loss of...'. Through these images, for the bar's owner, the major purpose of the pub is as a 'tribute to those that have lost their lives' in Britain's wars (TSB 2018).

Scholars of CMS demonstrate how 'death creates a strong discursive pressure for closure, giving the statements and images that are employed in remembrance a particular political salience' and that the 'recognition of the deaths within the context of war ... gives them meaning within the nationalist myth without constituting them as overly tragic or threatening' (Millar 2015, 759). In this way memorialisation praxis such as that in The Don can depoliticise and then re-politicise war whereby it focuses on remembering 'bodies broken by war when the wars that broke those bodies are forgotten' while reproducing 'the myth of a state and society that at once shies away from war but steps up to fight when necessary' (Basham, 2016: 887). As part of this process, soldiers, dead and/or memorialised, are 'joined to the state and curated as eternal military heroes' (Sylvester 2017, 152) part of collective memory and national identity.

Images and 'visual rhetoric' (Lucaites and Hariman, 2001) are endlessly significant in terms of the practices of war (cf. Bleiker 2018; Shepherd 2008) and its memorialisation (Basham 2016, Sylvester 2017, 2019; Welland 2017). Images of war that are iconic, symbolic or recognisable in some way (like, I would suggest, the figure of the young male soldier killed in war) are even more likely to 'reflect social knowledge and dominant ideologies, shape and mediate understanding of specific events and periods' (Lucaites and Hariman 2001, 37). Images in The Don are sticky with both intimacy (photos selected by loved ones) and martial symbolism (often depicting uniformed young men) as well as being immersive as a collection and demonstrating how 'images and artefacts visually depict and perform and thus politically frame a sense of identity and community' (Bleiker 2018 , 24). A large volume of visual material - images of dead soldiers and other aspects of (predominantly) British war-fighting along with other material artefacts - contribute to a sense of themed space (Lukas 2007, 2016) productive of an emotional sensation of nationalism and collectivity (cf. Bleiker 2018; Lisle 2007; Rai 2018) with particular political effects.

The images in The Don (photographs and posters) are objects themselves, and act in conjunction with other objects that also do theming work. War objects are not singular self-contained things but are bound up with assemblages (Bennett 2010) and configurations which signal certain imaginaries and provoke particular narrative fragments (Mac Ginty 2017). For instance, an early model gas mask displayed in the British context is likely to signal fragments of narratives about trench-warfare, mustard gas, a time when German soldiers were 'the enemy' (Malvern 2001). It provokes certain affects and emotions linked to a (very context-specific) conception of particular times - perhaps in the case of the gas mask a more innocent, committed, collectivist sensation of nationalism and 'Englishness' (see Malvern 2001) connected to rations, munitions factories, war poets and a nation pulling together. This is parallels what Basham $(2016 \mathrm{~b}, 259)$ refers to as 'Blitz spirit'.

Artefacts of war, evoking 'pastness', play an important role in establishing the contemporary identity of a given political community, since, as Sylvester articulates, 'things are needed to provide tangible proof that the nation had a memorable past, an honorable past, a prestigious past, a past the world 
can mark and that the nation can protect today' (Sylvester 2009, 55 emphasis added). Objects of war can be productive of, share, circulate and assemble-together certain war-linked affects and emotions. Sylvester (2017) highlights this when arguing that 'as new materialist accounts suggest, 'things' have power to connect viewers to emotional forms and experiences of knowledge'. Reeve suggests that aspects of 'material culture' - the collection and trade of 'war relics' such as 'unexploded ordnance and pieces of shrapnel' and the display of 'material ephemera' - helped British civilians bombed during World War I to make sense of their experiences. Thus 'memory objects' served as a mechanism through which to 'mourn the loss of loved ones and mark the passing of a bombardment' (Reeve 2019, 2). In these instances, chains of meaning are generated though the relationality between things and humans, their intra-action and mode of encounter, each agential in a capacity to impact upon the other to a degree (cf. Barad 2003; Bennett 2010). Objects, such as the weapons, uniforms, wooden crosses, poppies and a ration book on show in The Don produce and sustain cultural repertoires of temporal imaginaries and thus are part of how the past is configured in the present (Basham, 2016). Objects like this thus assert sets of temporal linkages, bound-up with forms of social construction and the operation of nationalism, nostalgia, emotion and abstract memory (Ahmed 2015; Gentry 2015). Additionally, while in other contexts these objects might appear simply as curiosities, the 'tribute' to war dead in The Don lends these objects additional emotive resonance and gravitas by association.

Importantly, though there are flags of other nations hanging from the ceiling and persons of other nations are visible occasionally, The Don is an informal site of memorialization filled with images and objects linked primarily to Britishness. This is a Britishness conjured through nostalgic renditions of 'pastness', through the setting up of war as at the heart of British history and (via affective sensations of community and actual charity work and care, as discussed below) of contemporary collectivist values in an age of austerity. Theming around the first and second world wars feature heavily (evoking, I suggest 'Blitz spirit'). At times this is cartoonish, with iconic pastiche period posters of 'pin-up girls' and sexual health warnings. At other times, as with the emphasis on the experience of two second-world war veterans in the TSB-sponsored film, and as evidenced by comments on Tripadvisor, it conveys a sense of patriotic respectfulness. The war/military theme in and circulating around The Don cuts across temporal and contextual specifics via semiosis (diverse items presented as a logical whole) thus offering a unifying nationalist centre-point whereby soldiers and various war-related objects appear 'joined to the state'. Central to the discourse surrounding the bar and elevating the theming praxis as something beyond a commercial theming site (unlike other war themed bars such as Cahoots Underground, which is an unquestionably light-hearted rendition of generic post-Second World War (ish) imaginaries) is the idea that this is a space of remembrance and respect as well as being part curated through a community of mourning.

Neloufer de Mel $(2007,17)$ argues that '[t]he use of historical memories, whether of past wounds, victories, heroes or legends, and the public management of memory are key elements in the processes of militarization'. As such, I pay attention to The Don as a political site of 'everyday IR' and curated, community militarism, that obscures extreme violence (including against unarmed civilians) even as it also affectively trends towards compassion and care. Feminist scholars continue to show that regimes of war memorialisation and exhibition (re)produce particular understandings of race and gender, often with an attendant privileging of maleness (and via militarized masculinity - the binding together of the values of soldiering with the values of tough, brave and stoic machismo) and whiteness (cf. Henry 2018; Welland 2017), and The Don also has a gendered and racialized politics cutting though its martial community praxis as I highlight below. 
In general, even traditional war museums are hybrid affairs, a mix of history, contemporary demand, business, tribute; balanced between 'the twin tasks of selecting and displaying representative objects and images, and the unavoidable objective of attracting the public to come into it' (Winter 2012 , 152). Sylvester (2017) points out that the categories of museum and memorial can be interchangeable in some cases as memorials slip into museums through usage, though in these cases they lack the formality of official museums. Cooper, the owner of The Don, refers to it as a museum as well as a 'tribute' and it signals both a site of memorial and display (TSB 2018). In this sense it maps onto what Danilova $(2015,268)$ has called 'community-driven memorials' which 'result from the activities of ordinary citizens'.

The role of Cooper as someone who has chosen to shape their bar into a memorial and curate it accordingly, with community participation, is significant for understanding this space. Practices of curation are key to war memorialisation and its politics. Julia Welland (2017) has demonstrated how an Imperial War Museum exhibition on British participation in the war in Afghanistan produced forms of 'hypervisibility' (of the liberal warrior) and forms of 'invisibility' (of the dead or harmed Afghan civilian) which code and perpetuate particular war stories. Szitanyi argues that curation of war memory is heavily power-imbued since: '[i]n creating a space of military remembrance, museum designers have the power to decide what counts as fact and what does not, which information will be consumed and which will be forgotten' $(2015,225)$.

In The Don, curation practices work, I suggest, predominantly through notions of theming, producing an eliding effect. Many things linked to British war-making are collected and exhibited together, and though multiple images/objects from a particular war are grouped together in some instances, items are not necessarily or clearly delineated by type or time throughout. What this does is generate a sense of continuum and entanglement. Turning to the Tripadvisor reviews (2020), a phrase used by multiple patrons to describe the experience with The Don is 'past and present' or something similar, to signal the engagement with both contemporary veterans/soldiers/wars and those in the past, all on equal footing and altogether. The sheer mass of theming content and modes of abstraction such as the dominance of thousands of poppies, means that via strategies of semiosis particular dead are individualised while also signalling British soldiering writ large. Individuals are clearly delineated by their photographs, names, a fragment of their stories, and their wars, but the scale of the representation, and the immersive nature of it - you are literally surrounded by the symbolism and visuality of war and remembrance, covering all available wall and ceiling space - produce a sense of atemporal awe. There is a collapsing together of the distinct lives and, especially, deaths, represented and thus (if you are not mourning a specific person) the appropriate emotional response felt in reaction to the loss of a life is arguably channelled and defused across British warmaking in general. In generating a logic of appropriateness bound to emotions of loss, and awe at the scale of loss, as well as pride and togetherness there is an emotional governance at work, which obscures the specific politics of specific wars, and obfuscates the violences undertaken by the represented dead (Welland 2017). As Basham articulates '[w] hat is forgotten is telling' $(2016,884)$.

In terms of spatial sites, I suggest that The Don Bar, situated as a local, community, commercial and independently generated space that is rendered intelligible via appeals to nationalism and collective meaning, sits in a liminal position between the state and the everyday. Keeping in mind Basham's point that liberal military power is 'co-constituted by seemingly coherent discursive state practices and more inconsistent facets of everyday lived experience' $(2018,34)$, The Don seems a particularly salient space to explore how these dimensions interact. Saunders and Crilley have suggested that 'the pub is a spatial zone that can, and often does, embody a politics, from the local to the national to the global' $(2019,25)$. Saunders and Holland $(2018,121)$ describe the pub a third space where 
'identities of self and community merge' and geopolitically salient performances manifest through ritual practices (drinking, ordering etc.). The pub is thus a site of performative reproductions of particular kinds of micropolitics bound up with grand narratives (like nationalism) and geopolitical meaning (like global supply chains or episodes of conflict). A significant contribution of this article is my exploration of the pub (increasingly recognised within IR as a site of global politics) when it emerges as a space of war- theming, and what this does and means both spatially, materially and emotionally, and in terms of the study of martial politics in austerity Britain.

\section{War-Themed Space: Emotionality and Community}

[T]he experience of walking around looking at the exhibits, the crosses etc, talking to veterans, being made welcome is so humbling you feel quite emotional but very welcome.

\section{- Extract from Tripadvisor Review of The Don}

Research in geography has noted that certain kinds of pubs, in the context of austerity Britain and ailing high-streets, can be understood as 'community-fixers'; an investment in local industry that can bring people together, fixing decaying elements of community space and feeling (Hubbard 2019). The geographic location of The Don, in Stockton-upon-Tees is significant in this sense because it is an area of particularly high income-disparity, impacted badly by austerity, where employment opportunities for young people may be limited. As Basham (2016b) has pointed out, the British military historically relies heavily on young men from working-class backgrounds signing up and thus needs to promote military 'values' in working-class contexts and regions with fewer employment opportunities. Against the backdrop of austerity and keeping in mind Tidy's important argument that modes of charity and community position the military as an 'apolitical social cause' $(2019,221)$, I explore the idea of The Don through the prism of community here, taking into consideration the atmosphere, emotionality and aesthetics that create a sense of togetherness through inclusion and exclusion.

I suggest that The Don signals a community defined by care and compassion (especially of the veteran) and the martial power of an emotional atmosphere that is 'made' (see Tidy 2019) spatially through embodied labour and collective mourning, entangled with gendered and racialised logics. On the one hand, ideas of community and compassion in the wider context of austerity highlight the limitations of state care for those bodies it calls upon to fight in its wars, somewhat contesting the value of veteranhood as a social and nationalist condition (cf. Bulmer and Eichler 2017). On the other, the workings of martial emotionality, atmospheres of nationalism and the values espoused by charity and care, compound the underlying principles of austerity politics which rely on decentring responsibility for care onto 'the community' while at the same time, ironically, furthering nationalist sentiment though modes of 'Blitz spirit' (Basham 2016b, 259).

Taken together, the images, objects and spatial practices of The Don constitute a themed space, are immersive, and produce an emotional environment. Though I cannot argue that these emotions are uniformly felt, it is clear that some of the images and objects lean towards certain emotions and that they are collectively conducive to prominent affective sensations. One of the most notable and emotive features of the space is the many images of soldiers which have been sent in by mourning friends or family. Importantly, the images are very distinctly of soldiers, often largely devoid of the trappings of their civilian lives, and it is thus their deaths as soldiers that evoke a general kind of sadness and it is through their soldiering that their loss can be felt intimately and made knowable. Additionally, the wooden crosses and poppies covering the walls serve to indicate further, less knowable, but still national, predominantly military losses. Looking over the Tripadvisor reviews 
(2020) of the pub, emotionality is clearly expressed, ideas of sadness, respect, pride and awe pervade the comments. One customer states: 'On entering the bar the atmosphere of the place hits you'; one assures 'I guarantee you have never experienced anything like it'; while others make reference to the 'emotional' nature of their experiences. In one example a customer who also appears to be a soldier or veteran states: 'I've never felt emotional in a Bar before' as they detail their time in The Don. Copper told the Daily Mail (Duel 2015): 'I get veterans coming here and crying when they see the photographs I have on the walls along with the poppies. One actually broke down in front of me and said that the memorabilia meant so much to him and that he was overjoyed to be able to see it.'

The emotional nature of the experience is aligned to the sense of loss, some visitors have a specific loss in mind, while some signal emotionality in relation to the atmosphere of the space (see Closs Stephens 2016), the emotionality of military memory, and to the deaths of the great many soldiers who are represented on the walls and ceilings. The 'hypervisibility' (Welland 2017) of these war dead is at the core of the 'tribute' paid by the bar and sets it apart from many other war-themed pubs. The imaginary of the soldier here invokes 'a host of prior meanings and associations - such as existential threat, nationalism, sacrifice or common cause - that populate a Western social imaginary typified by remembrances of World Wars I and II' (Millar 2019, 202) and this is aided by visual guides which directly link to World Wars (WW) I and II such as images of soldiers who served in those wars, images of the holocaust, and historical propaganda posters. These prior meanings signal emotional responses, attachments and collective, traumatic loss. If 'emotions are ... part of how trauma is at once personally and socially "performed"', (Hutchison 2016, 81) then The Don is a site of performance that tracks between the general and the particular, the contemporary and the historical - specific loss, loss of so many.

The objects in The Don have a particular role to play in fostering the emotionality of the space. These objects are symbolic and productive of the national imaginary and the emotions of war pasts/presents (see Bleiker 2018). Malvern $(2001,59)$, writing about British WWI graves in France points out that 'wooden crosses ... had a powerful hold on popular imagination' (emphasis added). Wooden crosses of themselves, as objects, not just the graves, signal(led) something within collective British war imaginaries about collective sacrifice. These objects offer a possibility of temporal 'ground truth' (Tidy 2016) that is also purely hyperreal, they are of-war, memorabilia fragments that tether us simultaneously to a temporal encounter (a dated post-WWII ration book) and none; 'pastandpresent' (resonating with the theming technique of pastness). Additionally, alcohol as an object matters; the 'rituals of beer consumption' (Saunders and Holland 2018b) that take place in a pub offers embodied processes that resonate with rituals of mourning. As one Guardian writer (Freud 2014) put it: 'Alcohol was virtually invented for funerals. . Have one on the deceased's behalf.' The vital materiality (see Bennett 2010) of alcohol imbibed in a memorial, nostalgic space, where in the eyes of one visitor 'the theme is service personnel' (Tripadvisor 2020) enhances an atmosphere of collective, sad but also somehow resilient and celebratory praxis; a 'toast to fallen comrades'.

In the short TSB film (2018), two elderly veterans are featured, one in his late 90's and one in his late 80 's. Both men express how much the bar means to them, and how, if they were not there, they would be alone. Cooper, speaking of one man says, 'he's been coming in for about three year now [sic], he comes in every day, we look after him'. This man himself then tells us 'I get company, I like speaking to people and its better than being on your own'. Watching this video is an emotive experience, these two men evoke compassion and empathy and one (I suggest) feels glad that they have the support of The Don, Cooper and the community that is bound together by this space. 
Brought to the fore is also a radical welcomeness, reinforced by the comments on Tripadvisor. A veteran in the video states 'there are no strangers here, they're just friends that we haven't met yet' (2018). This welcomeness is fuelled by emotionality and togetherness and explicitly extended to 'all faiths and nationalities' (Cain 2017) evoking a sense of modern multicultural Britain. The two elderly veterans in the video are primarily indicative of a touching vulnerability and a need for human connection that stands in some contrast to the concept of militarised masculinity. The work of community emerges as distinctly personal and localised, potentially highlighting wider state neglect or impersonal forgetting of those it calls upon to fight its wars and betraying the idea that sacrifice on the part of the state will produce a mode of elevated citizenship. The sense is that veterans should be cared for, and it is up to the community - like that generated by The Don - to do that intimate, caring, almost familial, labour.

Drawing on emotions literature within IR (cf. Åhäll 2019; Ahmed 2015; Eroukhmanoff 2019) and critical geography (Closs Stephens 2016), I suggest that emotional atmospheres around The Donevoked in multiple aesthetic, spatial, material and narrative ways - seek to produce martial feelings especially about the figure of the soldier/veteran; sentiments which collectivise, produce community and arguably bind people to a sense of shared affective identity. These feelings are not necessarily automatically productive of pro-war politics and may centre on notions like the futility of war, but they none-the-less bind people together through emotionality, an emotionality that relies upon warmeaning. Moreover, emotions, in drawing a community together, are also generative of exclusions. As Gentry $(2015,135)$ articulates, drawing on Sara Ahmed and Martha Nussbaum, emotions, such as those created through memorialising sacrifice, can foster binaries: 'our emotions about a particular object will either unite or divide us from others.' The theming practices of the bar feed into this in various ways.

Bar owner Julie Cooper's embodied labour has a role to play here. She is very much the face of the bar, is highly visible online as the key promotor, creator and curator of this space and its tribute, and is regularly mentioned by others, such as those on Tripadvisor, as central to the experience of The Don. It is notable that Cooper has glued each poppy to the wall by hand, and states that she bears the scars of the glue gun as a result (TSB 2018). Tidy $(2019,221)$ has shown that the production of war crafts is an essential mode of militarism, with a distinct martial logic and that

analysing embodied registers of aesthetic expression and the social values and gendered relations that attend crafting for war reveals how such making is a space through which intimate embodied circulations of the material and the emotional obscure violence, normalize war, abstract the military to a seemingly apolitical social cause, and contribute to wider state logics and imperatives.

It is key then that, as reported by a Don patron on Tripadvisor 'Julie and her hard work have made it what it is' and that this embodied labour is noted as key to the production of The Don as a memorial space, since, as another customer notes, 'The Landlady / Angel, One Miss Julie Cooper, has attached every single poppy, every piece of memorabilia, personally'. Through this intimate material work as well as her care for clientele - and veterans in particular - Cooper emerges not only as a curator but as a generally supportive, nurturing and welcoming figure, a kind of paragon of home-front femininity: kind, materially productive and endlessly supportive. Moreover, as evidenced by a JustGiving page (the bar is moving location and needs funds) as well as numerous elements of charity and compassion evidenced physically and online (signs and online events signalling care for elderly veterans or the offering of free meals, and even at one point a Christmas shoe-box appeal for serving personnel (Blackburn 2016)) this home-front caring, 'making', maternal femininity helps to frame concepts of war, militarisation and nationalism, as 'a seemingly apolitical social cause' (Tidy, 
2019,221 ) as well as an intimately embodied family-like and compassionate community endeavour. This is compounded by Cooper's role as curator, offering bodily tribute (and bearing the scars) to those who have sacrificed, which feeds into a wider privileging of the female subject as the grieving subject echoing through history - '[r]ituals of mourning in post-war Britain were centred on women, who also symbolized the nation's grief' (Malvern 2001, 62) - once again linking the idea of the civilian war-making space (a space of mourning, compassion, care for 'our boys'), with the idea of the woman and woman's war contribution to community feeling.

As indicated above, often the narratives circulating around The Don are of a welcoming nationalism, a pride that is shared with all. In the promotional video, Cooper states 'different nationalities, different race, different colour [sic], it doesn't matter here, everybody is welcome' (Stories of Local Pride 2018). Within the bar itself there are notable images of Gurkhas (Nepalese soldiers), Sikh soldiers and an image and attached text celebrating Walter Tull, a black British war hero and officer during World War I (though there is no engagement with their racialized experiences, see for example Chisholm 2014). Female soldiers are much less visible than male in The Don, but a flag in tribute to Corporal Channing Day, a soldier killed in Afghanistan who was Northern Irish and mixedrace (Swinford and Farmer 2012) is prominent above the bar (and pictured in the Tripadvisor images) and arguably recognises the complex intersectionality of soldiering identities. There is some limited space for multiplicity here and the nostalgic (and aesthetic) prioritisation of whiteness associated with British nationalism (see Basham 2018, 36; Welland 2017) is discursively contested within the public narratives and visual praxis around The Don. The message of The Don thus chimes with wider liberal war-making imaginaries (and recruitment strategies) which articulate modes of inclusion and 'benevolent patriotism' (Lisle 2007).

Yet, Cooper is said to have begun her war decoration of the pub, her martial space-making, linked to 'the murder of Lee Rigby' (The Military Times 2018), a British soldier killed by two men in an act that 'rocked the nation' (Felix Allen and Mullin 2019). The killers were associated with 'Islamic extremism' (Siddique 2017) and the murder was distinctly connected to Rigby's identity as a British soldier (thus perceived as symbolic of the British military by his killers). The foundational logics of this handcrafted, community-curated, informal memorial are thus tied into the logics of the War on Terror, in which the liberal west is ideologically pitted against a radical and often racialised 'Other' (cf. Gentry 2015; Richter-Montpetit 2007; Razack 2008). Moreover Rigby's murder, as an act of violence, feeds into anxieties (see Gentry 2015) about the enemy within (again radicalised, racialised) (Basham 2016; Basham and Vaughan-Williams 2013).

As Gentry $(2015,135)$ points out 'when a nation 'mourns,' it may be mourning some bodies over others or some mourners may be more important than others' (see also Butler, 2010). The Don is explicitly a space where British soldiers are mourned as the central loss in war and contemporary war-affected populations are largely unrepresented, facilitating the knowability of the soldier as the untainted fallen hero. Moreover, at the time when I visited and in all the images taken by visitors available on Tripadvisor at the time of writing, the (racialized) contemporary 'enemy' is largely unvisible (see Welland 2017). Though this unvisibility is arguably normal for memorials (and for other war-themed pubs), it is interesting that aesthetically at least, different concepts/figures of enmity are mainly displaced by the small but distinct visibility of one key (and, perhaps significantly, both white and uncontestably evil) enemy - Hitler, who is depicted via a few cartoonish posters.

This again seems to chime with wider narratives of contemporary war-making. As Olsson $(2019,2)$ articulates: '[j] ust as contemporary Western wars are never declared, they also seem to lack officially defined 'enemies". Here the logics of elision and semiosis seem to be at work, so that temporalities are entangled, and wars - and their distinct and specific political logics of enmity - slide 
together. Thus obfuscated, enmity becomes a notion untethered to contemporary individuals, which denies any possibility of grievability, recognition or cause on the side of those who fight (and die at the hands of) the British military (Butler 2010; Partis-Jennings 2017).

Moreover, in the few images of Hitler I saw in The Don, there was a cartoonish sexualisation of enmity apparent. He is depicted bending down, with his buttocks exposed in a way to signal the possibility, indeed desirability, of sexual violence in a 'humorous' mode. Though she is writing specifically about neo-colonial violences, Richter-Monpetit's $(2007,46)$ argument that the 'heteropatriarchal association of the penetrated body as passive and feminine, and of the penetrator as virile and masculine has played, and continues to play, a significant role in military conquests' arguably explains the nature of these images. Enmity and the potential conquest of that enemy manifests in sexual terms, evoking sexual violence and the defeat of an enemy through symbolic penetration of their hated body (see also Mann 2006, 158). These images evoking the penetration of Hitler then are about masculinity, and the idea that to emasculate is to defeat, to penetrate is to hold power over (see Higate 2012). Thus, signalling a different kind of togetherness and community, the images are producing a sense of national collective masculinity through notions of power and conquest and the evocation of sexual dominance.

Taken together, these theming practices produce particular political effects. A sentence from one review on Tripadvisor highlights the collapse between military and community at this site: 'The place is unashamedly military orientated and does much for the ex forces and local community [sic].' The 'community-fixer' role of a pub like this, generated by its war-theming (which cultivates notions and emotions of collectivity) and the evident compassion for vulnerable veterans that is a core part of the identity of The Don, is a contestation of the austerity state, failing those it should care for. Yet the circulation of nationalist atmospheres through themed space, reproduce notions of a 'Blitz spirit' (in-group verses out-group, resilient togetherness) in the face of austerity (Closs Stephens 2016). This element privileges community care as part of a British value system, whereby 'we' $r$ all in this together' just like when we stood against Hitler (who, in this imaginary, is countered with emasculation/national masculine dominance). In this nostalgia-oriented emotional community identity, there is space for some racial diversity and women, though whiteness and male sacrifice are privileged, but the enemy Other and war dead killed at British hands are (not unexpectedly) not offered access to emotional recognition, nor even are they seen beyond implicitly through the violence they do in causing the deaths of British soldiers. My main point here is that in the context of austerity, the state relies on certain kinds of community to produce the caring labour it neglects and an ideological backdrop to smooth over hardship and in The Don, we see how this is entangled with war and militarism. The sense of community produced by war-theming is both productive of exclusions and erasures, and useful for the perpetuation of austerity. War-based theming is good for both togetherness and austerity politics.

\section{Eliding the Veteran}

While in The Don, I noticed a British flag with the image of a soldier in the centre and text reading 'Justice for the Northern Ireland Veterans - Stop the Witch Hunt Now!' as well as a sign saying 'We Support our Northern Ireland Veterans - Do Not Betray Them for Doing Their Job'. The bar was also promoting a wider campaign around so-called 'Soldier $\mathrm{F}$ ' and other veterans, centred on a special screening of the documentary The Great Betrayal, a strident defence of British military action in Northern Ireland, which is advertised on the website of the 'Justice for Northern Ireland Veterans' campaign. 'Soldier F' is a British veteran accused of the murder of two people and attempted murder of four others, when his military unit, the Parachute Regiment, opened fire on peaceful civil rights protesters in Derry in 1972 on what would become known as 'Bloody Sunday' (Sabbagh 2019). 
The prosecution of 'Soldier $F^{\prime}$ is part of a wider effort to hold soldiers accountable for civilian killings in Northern Ireland, which has been deeply political, especially with the appointment of a new UK Minister for Veteran Affairs who is stanchly opposed to any prosecutions (Sabbagh 2019), and within the context of wider Brexit-based tensions over the fate of Northern Ireland. The 'Justice for Northern Ireland Veterans' campaign, mentioned above, frames its purpose thus:

Justice for Northern Ireland Veterans is specifically dedicated to the support of men and women who signed a blank cheque for their lives in order to fight terrorism and protect the general public in a forgotten war that successive British Governments have been too embarrassed to acknowledge.

It is clear from this statement that this campaign is portrayed as a marginal one, with supporters of 'Soldier F' claiming he had been 'stabbed in the back' (Roberts 2019) by the those in power. As highlighted by Andrews $(2017,48)$ the soldier/veteran takes on greater significance as a national symbol in times of austerity:

the current economic crisis and call for austerity has given rise to a new popular hero, the British Tommy ... the Tommy is presented as something of a tragic hero, bravely making his 'own history' but in circumstances which are not of his own choosing.

The 'Soldier F' campaign framing chimes with the idea of the 'British Tommy' as a 'tragic hero' especially within the remit of hardship-oriented austerity politics and a subsequent need for loyalty and togetherness in the face of betrayal (whereby the 'British Tommy' of WWI stands in for ordinary British soldiers in general). In fact, the campaign has powerful supporters. UK Prime Minister Boris Johnson explicitly gave his 'backing to a public campaign supporting UK soldiers who served during the Troubles' (McGuinness 2019) and has called the prosecutions 'unfair'.

As Bonnie Mann $(2006,151)$ writes, war 'depends on the successful production of an aesthetic of war that feels like our own skin, that is intertwined with the roots of our identities, that works someplace where critical scrutiny fails'. I suggest that the production of themed space at work in The Don exemplifies in a concentrated fashion the wider creation of an aesthetic of war-bound community and martial feelings which craft particular forms of political encounter with the soldier/veteran. The veteran becomes known through immersive praxis in which soldiers and former soldiers are intimately, but collectively, mourned, while at the same time are 'tied to the state' though the political discourse and symbolism that accompany this aesthetic knowability. As such the possibility of even investigating atrocity violence is framed as injustice and a betrayal of 'our' very identities. It is significant that The Don hosted a showing of The Great Betrayal, and displays a flag framing the prosecution of Soldier F as a 'witch hunt', denying any possibility that ascertaining the truth about this soldier's participation in Bloody Sunday is legitimate and paralleling Boris Johnson's statement that 'we need to end unfair trials of people who served their Queen and country' whereby he discursively collapses specific veterans into the idea of veterans collectively as heroic, selfsacrificing figures.

Here then, the more explicit politics of the practices of elision and semiosis within The Don are entangled with and feed into a wider politics of war justification and immunity for violence that circulate around liberal militarism, martial austerity politics, British nationalism and colonial histories. In The Don the aesthetics and curation of the bar single out individuals through images, but taken as a whole, through theming strategies, the individual is subsumed within a wider logic of nationalism, sacrifice, tribute and the war-bound community. As everything is experienced immersively through themed space there are few distinctions between the possible meanings of the 
veteran, or the wars they took part in, or the way they fought those wars. Indeed, it is telling that a sign attached to the outside of The Don which depicts a British flag with silhouettes of soldiers, war planes and crosses stating: 'Past, Present - Total Respect'. Thus, the overarching sense is to mobilise the emotionality of this immersive site and lean towards an unquestioning politics of support for soldiers. Even though the brutal killings of peaceful protestors on Bloody Sunday that the Parachute Regiment are accused of took place, and even if they can be understood as war crimes and should be investigated, this investigation is being framed as injustice and a violation of 'British Tommy' hero status. As such war actors like 'Soldier F' are supported as aesthetically and emotionally constituted veterans whose individual acts are elided and subsumed within wider logics and frames of meaning for their(/our) war-making subjectivities to be(come) possible. I suggest that as a themed site, The Don produces aesthetic and community-focused logics of erasure and collapse which are significant in terms of understanding the wider project of liberal militarism in the context of austerity and modes of intelligibility that are also replicated at the level of elite political rhetoric.

\section{Conclusion}

In this article I have shown how engagement with the themed space of The Don means that the soldier/veteran is felt intimately and immersively, as a mode of knowing. I have shown that themed space 'made' through embodied labour and practices of care and compassion as well as of mourning forge emotional communities that signal specific political effects in times of austerity and in relation to potential immunity for atrocity crime in the context of British imperial war-making. This article builds on diverse and multidisciplinary insights to explore the understudied space of the war-themed pub as a crucial site of everyday liberal militarism delineated by aesthetic and material modes of immersion, memorialisation and affective praxis. It makes a significant contribution to ongoing conversations about martial memory-curation and the significance of emotional nationalism crafted through banal sites of encounter and embodied performances. Moreover, it further highlights the importance of the pub, especially in the context of the UK, to 'everyday IR' and complex configurations of national atmospheres and geopolitical ritual. Future avenues of research opened up by this kind of curiosity (see Basham 2016; Tidy 2019, 2015) might bring to the fore a wider research agenda around the 'making' of private and commercial spaces and the consumption of material objects and atmospheres as war-bound praxis, and further explore the nexus between neoliberal political and social economies of austerity (with related things, spaces and feelings) and the perpetuation of war and war-meaning.

\section{References}

Åhäll, Linda. 2018. "Affect as Methodology: Feminism and the Politics of Emotion." International Political Sociology 12: 36-52.

- - . 2019. "Feeling Everyday IR: Embodied, Affective, Militarising Movement as Choreography of War." Cooperation and Conflict 54 (2): 149-66.

Ahmed, Sara. 2015. The Cultural Politics of Emotion. 2nd ed. New York \& London: Routledge.

Andrews, Maggie. 2017. "Remembrance and the Working Class Soldier Hero in Austerity Britain." In Cultural Politics in the Age of Austerity, edited by David Berry, 47-66. London and New York: Routledge.

Barad, Karen. 2003. "Posthumanist Performativity: Toward an Understanding of How Matter Comes to Matter." Signs: Journal of Women in Culture and Society 28 (3): 801-31. 
Basham, Victoria. 2009. "Effecting Discrimination: Operational Effectiveness and Harassment in the British Armed Forces." Armed Forces \& Society 35 (4): 728-44.

Basham, Victoria M. 2018. "Liberal Militarism as Insecurity, Desire and Ambivalence: Gender, Race and the Everyday Geopolitics of War." Security Dialogue 49 (1-2): 32-43.

Basham, Victoria M. 2016a. "Gender, Race, Militarism and Remembrance: The Everyday Geopolitics of the Poppy." Gender, Place \& Culture 23 (6): 883-96.

- - - 2016b. "Raising an Army: The Geopolitics of Militarizing the Lives of Working-Class Boys in an Age of Austerity." International Political Sociology 10: 258-74.

Basham, Victoria M, and Nick Vaughan-Williams. 2013. "Gender, Race and Border Security Practices: A Profane Reading of 'Muscular Liberalism.'” The British Journal of Politics and International Relations 15: 509-27.

BBC News. 1999. "The NHS: The Conservative Legacy," September 20, 1999.

http://news.bbc.co.uk/1/hi/health/background_briefings/your_nhs/85952.stm.

Bennett, Jane. 2010. Vibrant Matter: A Political Ecology of Things. Durham and London: Duke University Press.

Björkdahl, Annika, and Susanne Buckley-Zistel, eds. 2016. Spatializing Peace and Conflict: Mapping the Production of Places, Sites and Scales of Violence. Hampshire and New York: Palgrave Macmillan.

Blackburn, Mike. 2016. "Stockton Landlady Aims to Give Teesside Squaddies Overseas Some Christmas Cheer!" TeessideLive, October 7, 2016. https://www.gazettelive.co.uk/news/teessidenews/stockton-landlady-aims-give-teesside-11994049.

Bleiker, Roland. 2015. "Pluralist Methods for Visual Global Politics." Millennium - Journal of International Studies 43 (3): 872-90.

- - . 2018. "Mapping Visual Global Politics." In Visual Global Politics, edited by Roland Bleiker. London and New York: Routledge.

Bulmer, Sarah, and Maya Eichler. 2017. "Unmaking Militarized Masculinity: Veterans and the Project of Military-to-Civilian Transition." Critical Military Studies 3 (2): 161-81.

Burke, Edward. 2018. An Army of Tribes. Liverpool: Liverpool University Press.

Butler, Judith. 2010. Frames of War: When Is Life Grievable. Verso.

Cain, James. 2017. "'We're Not Racist': Owner of War Memorial Bar to Hold Open Day to Stop 'Unfounded' Rumours." TeessideLive, October 29, 2017.

https://www.gazettelive.co.uk/news/teesside-news/were-not-racist-owner-war-13828764.

Chisholm, Amanda. 2014. "The Silenced and Indispensible." International Feminist Journal of Politics 16 (1): 26-47.

Conway, Brian. 2003. "Active Remembering, Selective Forgetting, and Collective Identity: The Case of Bloody Sunday." Identity: An International Journal of Theory and Research 3 (4): 304-23.

Danilova, Nataliya. 2015. "The Politics of Mourning: The Virtual Memorialisation of British Fatalities in Iraq and Afghanistan." Memory Studies 8 (3): 267-81. 
Dempsey, Noel. 2019. "UK Defence Personnel Statistics."

http://researchbriefings.files.parliament.uk/documents/CBP-7930/CBP-7930.pdf.

Duel, Mark. 2015. "Landlady Turns Her Pub into a War Memorial by Sticking 70,000 Poppies to the Walls and Ceiling in a Display That Reduces Veterans to Tears." The Daily Mail, November 5, 2015. https://www.dailymail.co.uk/news/article-3305510/Landlady-turns-pub-war-memorial-sticking-70000-poppies-walls-ceiling-display-reduces-veterans-tears.html.

Edensor, Tim. 2001. “Performing Tourism, Staging Tourism.” Tourist Studies 1 (1): 59-81.

Eroukhmanoff, Clara. 2019. "Responding to Terrorism with Peace, Love and Solidarity: 'Je Suis Charlie', 'Peace' and 'I Heart MCR.'” Journal of International Political Theory 15 (2): 167-87.

Felix Allen, and Gemma Mullin. 2019. "FUSILIER MURDER When Was Lee Rigby Murdered and Who Were His Killers Michael Adebolajo and Michael Adebowale?” The Sun, May 22, 2019. https://www.thesun.co.uk/news/3629582/lee-rigby-death-killers-michael-adebolago-adebowaleanniversary/.

Freud, Emma. 2014. "How to Do a Funeral." The Guardian, 2014. https://www.theguardian.com/lifeandstyle/2014/jan/04/emma-freud-guide-how-to-do-funeral.

Gentry, Caron E. 2015. "Anxiety and the Creation of the Scapegoated Other." Critical Studies on Security 3 (2): 133-46.

Ginty, Roger Mac. 2017. "A Material Turn in International Relations: The 4x4, Intervention and Resistance." Review of International Studies 43 (5): 855-74.

Halliday, Josh. 2017. "Different Worlds, 300 Meters Apart: How Two Areas Sum up Middlesborough's Fate." The Guardian, April 26, 2017. https://www.theguardian.com/cities/2017/apr/26/differentworld-middlesbrough-tees-valley-mayor-election.

Heck, Axel, and Gabi Schlag. 2013. "Securitizing Images: The Female Body and the War in Afghanistan." European Journal of International Relations 19 (4): 891-913.

Henry, Marsha G. 2018. "Why Critical Military Studies Needs to Smash Imperial White Supremacist Capitalist Heteropatriarchy: A Rejoinder." Critical Military Studies 0 (0): 1-4.

Higate, Paul. 2012. "Drinking Vodka from the 'Butt-Crack': Men, Masculinities and Fratriarchy in the Private Militarized Security Company." International Feminist Journal of Politics 14 (4): 450-69. https://doi.org/10.1080/14616742.2012.726092.

Hubbard, Phil. 2019. "Enthusiasm, Craft and Authenticity on the High Street: Micropubs as 'community Fixers.'” Social \& Cultural Geography 20 (9): 763-84.

Hutchison, Emma. 2016. Affective Communities in World Politics. Cambridge, New York: Cambridge University Press.

Kennedy-Pipe, Caroline. 1997. The Origins of the Present Troubles in Northern Ireland. 2013thed. Oxon and New York: Routledge.

Kothari, Uma. 2006. "Spatial Practices and Imaginaries: Experiences of Colonial Officers and Development Professionals." Singapore Journal of Tropical Geography 27 (3): 235-53.

Lisle, Debbie. 2007. "Benevolent Patriotism: Art, Dissent and the American Effect." Security Dialogue 38 (2): $233-50$. 
Lucaites, John Louis, and Robert Hariman. 2001. "Visual Rhetoric, Photojournalism, and Democratic Public Culture." Rhetoric Review 20 (1/2): 37-42.

Lukas, Scott A. 2007. The Themed Space: Locating Culture, Nation, and Self. Plymouth: Lexington Books.

- - . 2016. "Introduction: The Meanings of Themed and Immersive Spaces." In A Reader in Themed and Immersive Spaces, edited by Scott A. Lukas. Pittsburgh, PA: Carnegie Mellon: ETC Press. Malvern, Sue. 2001. "War Tourisms: 'Englishness', Art, and the First World War." Oxford Art Journal 24 (1): 47-66.

Mann, Bonnie. 2006. "How America Justifies Its War: A Modern / Postmodern Aesthetics of Masculinity and Sovereignty." Hypatia 21 (4): 147-63.

McGuinness, Alan. 2019. "Boris Johnson Promises to End 'Unfair' Prosecutions of Northern Ireland Veterans." Sky News, July 12, 2019. https://news.sky.com/story/boris-johnson-promises-to-endunfair-prosecutions-of-northern-ireland-veterans-11761485.

Mel, Neloufer de. 2007. Militarizing Sri Lanka: Popular Culture, Memory and Narrative in the Armed Conflict. Sage Publications.

Millar, Katharine M. 2019. "The Plural of Soldier Is Not Troops: The Politics of Groups in Legitimating Militaristic Violence.” Security Dialogue 50 (3): 201-19.

Millar, Katharine M. 2015. "Death Does Not Become Her: An Examination of the Public Construction of Female American Soldiers as Liminal Figures." Review of International Studies, 1-23.

Möller, Frank. 2007. "Photographic Interventions in Post-9/11 Security Policy." Security Dialogue 38 (2): 179-96.

Partis-Jennings, Hannah. 2017. "Military Masculinity and the Act of Killing in Hamlet and Afghanistan." Men and Masculinities.

Rai, Shirin M. 2018. "Nation." In Visual Global Politics, edited by Roland Bleiker, 215-19. Oxon, New York: Routledge.

Razack, Sherene H. 2008. Casting Out: The Eviction of Muslims from Western Law and Politics. Toronto, Buffalo and London: University of Toronto Press.

Reeve, Michael. 2019. “'Are We Downhearted? NO!': Representing War Damage and Destruction Following Bombardment on the First World War 'Home Front'." Critical Military Studies 0 (0): 1-21.

Richard Bilton. 2018. "Dying Young in Stockton - England's Most Unequal Town." BBC News, July 30, 2018. https://www.bbc.co.uk/news/health-44985650.

Richter-Montpetit, Melanie. 2007. "Empire, Desire and Violence: A Queer Transnational Feminist Reading of the Prisoner 'Abuse' in Abu Ghraib and the Question of 'Gender Equality.'" International Feminist Journal of Politics 9 (1): 38-59.

Roberts, Joe. 2019. "Veterans Say the Government 'has Stabbed Bloody Sunday Soldier F in the Back."' The Metro, April 12, 2019. https://metro.co.uk/2019/04/12/veterans-say-governmentstabbed-bloody-sunday-soldier-f-back-9188237/. 
Sabbagh, Dan. 2019. "Sinn Féin Raises Fears over Proposed Amnesty for British Soldiers." The Guardian, July 29, 2019. https://www.theguardian.com/uk-news/2019/jul/29/sinn-fein-concernedthat-soldiers-amnesty-will-include-troubles.

Saunders, Robert A, and Rhys Crilley. 2019. "Pissing On the Past : The Highland Clearances, Effigial Resistance and the Everyday Politics of the Urinal." Millennium: Journal of International Studies 0 (0): 1-26.

Saunders, Robert A, and Jack Holland. 2018a. "The Ritual of Beer Consumption as Discursive Intervention: Effigy, Sensory Politics, and Resistance in Everyday IR." Millennium - Journal of International Studies 46 (2): 119-41.

- - . 2018b. "The Ritual of Beer Consumption as Discursive Intervention: Effigy, Sensory Politics, and Resistance in Everyday IR." Millennium - Journal of International Studies 46 (2): 119-41.

Shapiro, Michael J. 2008. "Slow Looking: The Ethics and Politics of Aesthetics." Millennium: Journal of International Studies 37 (1): 181-97.

Shepherd, Laura J. 2008. "Visualising Violence: Legitimacy and Authority in the 'war on Terror."” Critical Studies on Terrorism 1 (2): 213-26.

Stephens, Angharad Closs. 2016. "The Affective Atmospheres of Nationalism." Cultural Geographies 23 (2): 181-98.

Stories of Local Pride - The Don War Memorial Bar. 2018.

https://www.youtube.com/watch?v=gGSy21nMNtl.

Swinford, Steven, and Ben Farmer. 2012. "Channing Day: Family Pay Tributes to 'Beautiful, Wonderful' Daughter." The Telegraph, October 26, 2012.

https://www.telegraph.co.uk/news/worldnews/asia/afghanistan/9635233/Channing-Day-Familypay-tributes-to-beautiful-wonderful-daughter.html.

Sylvester, Christine. 2017. "Curating and Re-Curating the American War in Vietnam." Security Dialogue 49 (3): 151-64.

- - - 2019. "Who Curates Recent American Wars? Looking in Arlington Cemetery and at The Wall That Heals." Critical Military Studies 0 (0): 1-15.

Szitanyi, Stephanie. 2015. "Semiotic Readings of the USS Midway Museum." International Feminist Journal of Politics 17 (2): 253-70.

Tees, BBC. 2016. “The Don War Memorial Bar.” Facebook. 2016.

https://www.facebook.com/bbctees/videos/10153632602001714/.

The Military Times. 2018. "The Don War Memorial Bar Annual Parade and Fundraiser," April 1, 2018. https://www.themilitarytimes.co.uk/hm-forces/the-don-war-memorial-bar-annual-parade-andfundraiser/.

Tidy, Joanna. 2015. "Forces Sauces and Eggs for Soldiers: Food, Nostalgia, and the Rehabilitation of the British Military." Critical Military Studies 1 (3): 220-32.

- - . 2016. "The Gender Politics of 'Ground Truth' in the Military Dissent Movement: The Power and Limits of Authenticity Claims Regarding War." International Political Sociology 10 (2): 99-114.

- - . 2019. "War Craft: The Embodied Politics of Making War." Security Dialogue 50 (3): 220-38. 
- - - 2017. "Violence and the Contemporary Soldiering Body." Security Dialogue 48 (6): 524-40.

Winter, Jay. 2012. "Museums and the Representation of War." Museum and Society 10 (3): 150-63. 